\title{
Utilization of Low-cost Agricultural Waste for Removal of Toxic Metals from Environment: A Review
}

\author{
Snigdha Singh ${ }^{1}$, Indra Jeet Chaudhary ${ }^{2}$, Pankaj Kumar ${ }^{3 *}$ \\ ${ }^{1,2,3}$ School of Environment and Sustainable Development, Central University of Gujarat, Gandhinagar, Gujarat, 382030, India \\ *Corresponding Author: pankajb434@yahoo.com, Tel.: +918460571814
}

Available online at: www.isroset.org

Received: 02/Jul/2019, Accepted: 14/Aug/2019, Online: 31/Aug/2019

\begin{abstract}
Rapid urbanization and industrialization are the leading causes of environmental pollution nowadays. Heavy metals are serious toxic pollutants in soil, water, and air environments. Anthropogenic activity including industrial waste and dust is a widely known source for metal pollution. Various techniques are being used including ion-exchange, membrane filtration, electrolysis, coagulation, flotation, and adsorption for the removal of heavy metals from the environment. However, these techniques have high operating cost, sludge generation and selectivity of metals. Among them, heavy metal removal by the plant is an eco-friendly, sustainable, rapid and economic process. The adsorbent capacity of metal ions by plant and its removal varies, depending on the nature of the plants, particle size, and metal concentrations. This review paper focuses on the idea of using various agricultural wastes for the removal of heavy metals and also a way to management of waste generated by agriculture field. In this context, agricultural biomass is the best technique for the removal of heavy metals and need to improve the utilization of agricultural waste as sustainable way.
\end{abstract}

Keywords: Toxic metals, Removal efficiency, Agricultural waste, Adsorbent, Plant tolerance power.

\section{INTRODUCTION}

Agricultural waste material including biomass burnt or naturally converted into organic fertilizer under favourable condition. But nowadays biomass produced from agricultural waste is used to generate energy and the effective utilization of agricultural waste is a good option to use as metal removal. For these efforts have been made and many more are underway, it requires guidelines concerning the utilization of agricultural biomass for a sustainable management tool for metal removal.

Toxic substances including heavy metals are hazardous to the environment, as they are non-biodegradable and toxic in nature [1]. Toxicity of metal poses many diseases in humans including cancer, nervous disorder, organ failure, growth reduction and abdominal pain [2-3]. The metals concentration in the environment is found due to the discharges of industrial effluents from many industries such as tanneries, textile, pulp, paper, chlore-alkali, electroplating, fertilizers, dying, battery manufacturing and mining operations which creates metal toxicity [4-5].

Removal of toxic metal from soil, water, and air environment uses various methods including ion exchange, chemical precipitation, membrane separation, electrochemical coagulation, photo-catalysis, reverse osmosis, electrodialysis, solvent extraction, evaporation, etc. [6-12]. These methods are expensive and not effective. Adsorption is an effective and attractive purification and separation technique used especially in the industry for water and wastewater treatment [13]. The process of adsorption is an advantage over other methods due to its sludge-free clean operation. The manufacturing and regeneration costs are very high [14]. Thus, the demand of the hour is a low-cost adsorption system for which some attempts have been made to find a low-cost alternative adsorbent with high efficiency.

In recent years, considerable attention has been given to study the application of agricultural waste materials for heavy metal removal. The use of agricultural wastes or lignocellulosic materials such as rice husk, sawdust, wheat straw, orange peels, baggase, peanut shells, etc. is an effective method due to their availability in abundance (naturally or as by-products from waste industry), low cost, being environmentally friendly, feasibility for physical and chemical modification, and good adsorption capacity of heavy metals from wastewater [15-16].

The purpose of this review paper is to collect information on the use of various agricultural wastes as a sustainable way to removal of metal and management of waste generated from the agricultural field. This paper also aims to review the applicability of plants for metal removal from the 
environment as it is a cost-effective and eco-friendly technique of metal removal.

\section{SOURCES OF HEAVY METALS AND ITS IMPACT ON AIR, WATER AND SOIL ENVIRONMENT}

Heavy metal originates as a natural constituent of earth crust as well as from anthropogenic activity. Heavy metal persists in the environment and it cannot be degraded. Metals enter the body through food, air, and water and bio-accumulate over a period of time [17]. Sources of heavy metal differ from place to places. Minerals weathering, erosion, and volcanic activity are the most significant natural sources while for anthropogenic sources are mining, smelting, electroplating, use of pesticides and fertilizers as well as biosolids in agriculture, sludge dumping, industrial discharge, atmospheric deposition, etc. [18-19]. The most common and important heavy metals as a contaminant in the environment are $\mathrm{As}, \mathrm{Sr}, \mathrm{Cs}, \mathrm{U}, \mathrm{Cd}, \mathrm{Cr}, \mathrm{Cu}, \mathrm{Hg}, \mathrm{Pb}$ and $\mathrm{Zn}$ [20-21]. Some of these metals are micronutrients necessary for plant growth and development, such as $\mathrm{Zn}, \mathrm{Cu}, \mathrm{Mn}, \mathrm{Ni}$, and $\mathrm{Co}$, while others have an unknown biological function, such as $\mathrm{Cd}, \mathrm{Pb}$, and $\mathrm{Hg}$ [22]. Heavy metal poses toxic effects on human health and causes several serious diseases. Elements with metallic properties and an atomic number $>20$ are the conventional definition of heavy metals. Naturally, metals are normal components in soils. However, in high levels, metals can be toxic for plants, animal and microbes [23]. The heavy metal pollutant is a substance causes negative effects on life and reducing the quality of the environment and eventually causing death. These types of substances present in the environment acceptable as tolerance limit. Hence, environmental pollution such as air, water, and soil, which may be poisonous or toxic and caused harmful effects on a living being. They are global problems that are a growing threat to the environment.

\section{HEAVY METAL REMOVAL EFFICIENCY OF AGRICULTURAL WASTE}

Biomass of agriculture contains hemicelluloses, cellulose, lignin, protein, sugar, water, starch, and various functional groups, i.e., amine, aldehyde, hydrocarbons, keto group. Such properties enhance the efficiency of agricultural product and by-products in wastewater treatment. Agricultural biomass has properties viz. eco-friendly, wide availability, cheap in nature and material diversity. Some agricultural biomasses have been studied in the removal of toxic metal ions from aqueous solutions viz. stalk, husk, bagasse, fibre, shells, and straw.

Several previous studies have described the potential of plant as heavy metal bio-accumulator from contaminated soil and water. The studies have indicated the use of plants through phytoremediation technology is an alternative solution to treat heavy metal contaminated areas and can be used to remediate the environment. Table 1 and 2 summarizes the list of several plants and their part reported for heavy metals remediation. Each different plant has also different responses to different heavy metals exposure. Several plants are sensitive while other plants have a high tolerance to toxic metals. As a consequence of plant-metal interaction, numerous plants accumulate heavy metals from soil and have growth and development decreases. However, some plants have a high tolerance and can keep the growth and development as well under heavy metals stress.

\section{DIFFERENT PART OF PLANT (STALK, HUSK, BAGASSE, FIBRE, SHELL AND STRAW) FOR REMOVAL EFFICIENCY OF HEAVY METAL}

Various part of the plant including Stalk, Husk, Bagasse, Fibre, Shell, and Straw play an important role for removal of heavy metals. In this review, we are describing the various agricultural plants and their part as a waste for removal of heavy metals. In this constant, different types of agriculture plant stalk (sunflower, Zea maize, and corn) have been used as an adsorbent of several heavy metals in aqueous solutions [24]. A study reported by Zheng et al [25-26] the biosorption properties were improved by corn stalk. The husk is a part of agricultural residue, produced from several processes used in the removal of different metal ions in aqueous solution. A study reported by Wong et al. [27] used modified rice husk prepared by tartaric acid and carboxylic acid in removal of $\mathrm{Cu}$ (II) and $\mathrm{Pb}$ (II) ions adsorption reported 29 and $108 \mathrm{mg} / \mathrm{g}$ at $27 \pm 2^{\circ} \mathrm{C}$. Bagasse, a composition of lignin, pentose and cellulose as main constituents, is an agricultural solid waste obtains from the sugar industry. Its absorption capacity was higher due to the presence of diverse functional groups such as carboxylic, carbonyl, amine and hydroxyl, which helps in the binding of metal ions through cation exchange on adsorptive sites [28]. Adsorption capacities of Bagasse for the different metal ions are given in Table 1 . The composition of plant fibre is including cellulose, hemicellulose, lignin, pectin and extractives (fat, waxes, etc.). Various functional groups are also present in fibre which are responsible for adsorption of metal, carboxylic (including hemicelluloses, pectin, and lignin), phenolic (lignin and extractives), hydroxylic (cellulose, hemicelluloses, lignin, extractive, and pectin) and carbonyl group (lignin) [29]. Shells are the part of plant and used as low-cost adsorbents in removal of toxic pollutants from water. Ismaiel et al. [30] reported the potential of modified palm shell activated carbon in the removal of $\mathrm{Hg}$ (II) ions in aqueous solutions through batch-adsorption techniques. They observed that the efficiency of mercury removal increased with increasing contact time and increasing initial metal concentration. The increment of removal efficiency was found to be $83.33 \mathrm{mg} / \mathrm{g}$ at room temperature and $\mathrm{pH} 8$, with a 
contact time of 3 hours while an initial concentration of 10$200 \mathrm{mg} / \mathrm{L}$. Straw is mainly produced from the agricultural activities and mainly used in paper industry and as fodder for animals. The various study reported that different types of straw, such as wheat straw, barley straw, and rape straw, have potential in metal sequestration from wastewater. Biosorption potential of unmodified rice in the efficient removal of Cd (II) ions was reported by Ding et al [31]. The maximum biosorption capacity was noted $13.9 \mathrm{mg} / \mathrm{g}$ at $\mathrm{pH}$ range of 2.0-6.0. When $0.5 \%(\mathrm{w} / \mathrm{v})$ rice straw was exposed to $50 \mathrm{mg} / \mathrm{mL} \mathrm{CdSO}_{4}$ solution with shaking at $150 \mathrm{r} / \mathrm{min}$ for $3 \mathrm{~h}$, about $80 \%$ of aquatic cadmium was absorbed and the cadmium content in rice straw reached $8-10 \mathrm{mg} / \mathrm{g}$. Gorgievski et al. [32] also reported the potential of wheat straw in the biosorption of $\mathrm{Cu}^{2+}, \mathrm{Ni}^{2+}$ and $\mathrm{Zn}^{2+}$ ions from synthetic solution. Adsorption of heavy metal ion was influenced by the $\mathrm{pH}$ value and the adsorbent dosage. The study showed that the adsorption process increased with increasing adsorbent dose and $\mathrm{pH}$ values. Removal of metal more than $90 \%$ was obtained at $\mathrm{pH}$ 3.0-7.0. Metal ion biosorption is depending on insignificantly on $\mathrm{pH}$ but significantly on temperature.

Table 1: Agricultural Biomass and Their Heavy Metal Adsorption Capacity

\begin{tabular}{|c|c|c|}
\hline Biomass & $\begin{array}{c}\text { Metal, pH and Adsorption } \\
\text { capacity } \\
(\mathrm{mg} / \mathrm{g})\end{array}$ & References \\
\hline \multicolumn{3}{|c|}{ Stalk biomass } \\
\hline $\begin{array}{c}\text { Corn stalk } \\
\text { (acrylonitrile } \\
\text { modified); Corn stalk } \\
\text { (raw) }\end{array}$ & $\mathrm{Cd}$ (II), 7, 12.73; Cd (II), 7, 3.39 & 25,26 \\
\hline Sunflower stalk & $\mathrm{Pb}$ (II), 5, 182; Cd (II), 5, 70 & 36 \\
\hline $\begin{array}{l}\text { Zea maize stalk } \\
\text { sponge }\end{array}$ & $\mathrm{Pb}$ (II), 6 $\pm 0.2,80$ & 37 \\
\hline \multicolumn{3}{|c|}{ Husk biomass } \\
\hline $\begin{array}{l}\text { Bengal gram (Cicer } \\
\text { arientinum) husk }\end{array}$ & $\mathrm{Cr}$ (III), 2, 91.64 & 38 \\
\hline Coffee husk & $\begin{array}{c}\mathrm{Cu} \text { (II), 4, 7.5; } \mathrm{Zn} \text { (II), 4, 5.6; Cd } \\
\text { (II), 4, 6.9; Cr (VI), 4, 7.0 }\end{array}$ & 39 \\
\hline Hazelnut husk carbon & $\mathrm{Cd}$ (II), 5, 61.35 & 40 \\
\hline Rice husk & $\begin{array}{c}\mathrm{Cr} \text { (III), 5-6, 30; Cu (II), 5-6, } \\
22.5\end{array}$ & 41 \\
\hline \multicolumn{3}{|c|}{ Bagasse biomass } \\
\hline Agave bagasee( raw) & $\begin{array}{c}\mathrm{Cd}(\mathrm{II}), 5,14 ; \mathrm{Pb}(\mathrm{II}), 5,36 ; \mathrm{Zn} \\
(\mathrm{II}), 5,8\end{array}$ & 42 \\
\hline Bagasse carbon & $\begin{array}{c}\mathrm{Cd}(\mathrm{II}), 4.5,38.03 ; \mathrm{Zn}(\mathrm{II}), 4.5, \\
31.11\end{array}$ & 43 \\
\hline $\begin{array}{c}\text { Sugarcane; Sugarcane } \\
\text { bagasse (untreated) }\end{array}$ & $\begin{array}{c}\mathrm{Cr}(\mathrm{VI}), 1.9,23.0 ; \mathrm{Pb}(\mathrm{II}), 5, \\
6.366\end{array}$ & 44,45 \\
\hline \multicolumn{3}{|c|}{ Fiber biomass } \\
\hline $\begin{array}{c}\text { Agave sisalana (sisal } \\
\text { fiber) }\end{array}$ & $\mathrm{Cd}$ (II), 7, 1.85; Pb (II), 7, 1.34 & 46 \\
\hline $\begin{array}{c}\text { Coconut fiber (with } \\
\text { pristine) }\end{array}$ & $\mathrm{Hg}$ (II), 2-10, 166.67 & 47 \\
\hline Citrus reticulata waste & $\mathrm{Pb}$ (II), 5, 83.77; Co (II), 7, & 48 \\
\hline
\end{tabular}

\begin{tabular}{|c|c|c|}
\hline $\begin{array}{c}\text { biomass } \\
\text { (modified with } \mathrm{NaOH} \text { ) }\end{array}$ & 95.55 & \\
\hline Ficus carica fiber & $\mathrm{Cr}(\mathrm{V}), 3,19.68$ & 49 \\
\hline Palm kernel fibre & $\mathrm{Cu}(\mathrm{II}), 5.01,20.12$ & 50 \\
\hline \multicolumn{3}{|c|}{ Shell biomass } \\
\hline Annona squamosa & $\mathrm{Pb}$ (II), 5, 90.93; Cd (II), 5, 71.0 & 51 \\
\hline Cashew nutshell & $\mathrm{Pb}$ (II), 5, 408.6 & 52 \\
\hline $\begin{array}{l}\text { Chrysophyllum } \\
\text { albidum seed shell }\end{array}$ & $\mathrm{Pb}$ (II), 5, 103.42 & 53 \\
\hline Pecan nutshell & $\begin{array}{c}\mathrm{Cr} \text { (III), 5.5, 93.01; Fe (III), 4, } \\
\quad 76.59 ; \mathrm{Zn} \text { (II), 5.5 107.9 }\end{array}$ & 54 \\
\hline $\begin{array}{c}\text { Walnut shells } \\
\text { (modified with } \mathrm{ZnCl2} \text { ) }\end{array}$ & $\mathrm{Hg}$ (II), 5, 151.5 & 55 \\
\hline \multicolumn{3}{|c|}{ Straw biomass } \\
\hline $\begin{array}{c}\text { Barley straw and } \\
\text { Barley straw (modified } \\
\text { with citric acid) }\end{array}$ & $\begin{array}{l}\mathrm{Cu} \text { (II), 6, 4.64; } \mathrm{Pb} \text { (II), 6, 23.20; } \\
\mathrm{Cu} \text { (II), 7, 4.64; } \mathrm{Cu} \text { (II), 7, } 31.71\end{array}$ & 56,57 \\
\hline Rape straw & $\mathrm{Cu}$ (II), $5,7.3$ & 58 \\
\hline Wheat straw & $\begin{array}{c}\mathrm{Cd} \text { (II), 6, 14.56; Cd (II), 6, } \\
39.22\end{array}$ & 59 \\
\hline
\end{tabular}

\section{OTHER AGRICULTURAL BIOMASS}

Palm flower (Borassus aethiopum) treated with acid $\left(\mathrm{H}_{2} \mathrm{SO}_{4}\right)$ and alkali $(\mathrm{NaOH})$ was established as bio sorbent in the removal of $\mathrm{Cr}$ (VI) and $\mathrm{Cr}$ (III) ions from aqueous solutions. The maximum adsorption capacities were $6.24 \mathrm{mg} / \mathrm{g}$ (raw material) and $1.41 \mathrm{mg} / \mathrm{g}$ (acid-treated) regarding $\mathrm{Cr}$ (III) elimination. For $\mathrm{Cr}$ (VI) ion, the maximum uptake was $4.9 \mathrm{mg} / \mathrm{g}$ (raw adsorbent) and $7.13 \mathrm{mg} / \mathrm{g}$ (acid-treated). The changes in functional groups in biosorption confirmed the experiment [33]. The use of weed as bio-adsorbent is a cheaper and eco-friendly technique in metal detoxification of the environment. In the above-mentioned biomass used in metal removal, some other materials like apricot stone, bael fruit, coir pith, and pine needles were also used in sequestration of various metals (Table 2). The adsorption performance of chemically modified cotton seed cake for lead (II) removal from aqueous solutions was tested. The adsorption capacity was found to be $115.86 \mathrm{mg} / \mathrm{g}$, i.e., 5.3 times advanced than that of commercial activated carbon $\left(21.69 \mathrm{mg} / \mathrm{g}\right.$ ) at $300^{\circ} \mathrm{K}$. The adsorption procedure followed pseudo-second-order kinetics which confirms the chemisorption as a rate-controlling process [34]. Bouhamed et al. [35] studied $\mathrm{H}_{3} \mathrm{PO}_{4}$ activated Tunisian date stones, as a low-cost adsorbent for $\mathrm{Cu}$ (II) ion removal from aqueous solutions. The optimum results were found at about $\mathrm{pH} 5$. The adsorption process followed pseudo-second-order kinetics. The data fitted the Langmuir and DubininRadushkevich isotherm models. The monolayer adsorption capacity was recorded as $31.25 \mathrm{mg} / \mathrm{g}$.

\section{CONCLUSION AND FUTURE SCOPE}

Burning of agricultural waste is a major cause of environmental pollution. Nowadays various techniques are used for agricultural waste management system including 
energy generation and compost formation. Toxic metal removal by agricultural waste is a sustainable way for environmental clean-up. Plants can be an alternative solution as a green technology to treat the heavy metal contaminated environment (soil, water, and air). According to previous studies, several plants have a high potential as heavy metals bio-accumulator and can be used for the removal process of heavy metals. Metal removal rate depends on the plant biomass harvested and metal concentration in harvested biomass. In the present scenario, heavy metal is a major problem for environment. The present study also referred that various agricultural waste can be used as an eco-friendly technology for heavy metal removal. As seen from the research literature related to the utilization of agricultural waste for removal of heavy metal as newer development technology. In future need to improve the utilization of agricultural waste for metal removal.

Table 2: Other Agricultural Biomass Heavy Metal Adsorption

\begin{tabular}{|c|c|c|}
\hline Agricultural Biomass & $\begin{array}{c}\text { Metal, pH and } \\
\text { Adsorption Capacity } \\
(m g / g)\end{array}$ & References \\
\hline Apricot stone & $\begin{array}{l}\mathrm{Pb} \text { (II), 6.5, 22.85; Co } \\
\text { (II) }, 9,111.11\end{array}$ & 60 \\
\hline Bael fruit & $\mathrm{Cr}(\mathrm{VI}), 2,17.27$ & 61 \\
\hline $\begin{array}{c}\text { Bagasse pith } \\
\text { (activated carbon) }\end{array}$ & Co (II), 6, 153.6 & 62 \\
\hline Coir pith & $\begin{array}{c}\mathrm{Co}(\mathrm{III}), 4.3,12.82 ; \mathrm{Cr} \\
\text { (III), 3.3, 11.56; Ni } \\
\text { (II), 5.3, 15.95 }\end{array}$ & 63 \\
\hline $\begin{array}{c}\text { Hibiscus rosa sinensis } \\
\text { dye waste }(H D W)\end{array}$ & $\begin{array}{l}\mathrm{Pb} \text { (II), 6, 90.909; Cd } \\
\text { (II), 6, 103.093 }\end{array}$ & 64 \\
\hline Hydrilla verticilata & As (III), 6, 11.65 & 65 \\
\hline $\begin{array}{l}\text { Immobilized beads of } \\
\text { Garcinia cambogia }\end{array}$ & As (III), 6, 704.11 & 66 \\
\hline $\begin{array}{c}\text { Parthenium } \\
\text { hysterophorus and } \\
\text { (modified with H2SO4) }\end{array}$ & $\begin{array}{c}\mathrm{Cr}(\mathrm{VI}), 1,24.5 ; \mathrm{Ni}(\mathrm{II}), \\
5,17.24\end{array}$ & 67,68 \\
\hline Pine cone & $\mathrm{Pb}$ (II), 5.2, 27.53 & 69 \\
\hline $\begin{array}{c}\text { Salvinia cucullata } \\
\text { (thermally activated } \\
\text { weed) }\end{array}$ & $\mathrm{Cr}(\mathrm{VI}), 1.7,247$ & 70 \\
\hline $\begin{array}{l}\text { Tea leaves (exhausted } \\
\text { and exhausted) }\end{array}$ & $\begin{array}{c}\mathrm{Pb} \text { (II), 1-6, 120.8; Zn } \\
\text { (II), 1-6, 79.76 }\end{array}$ & 71 \\
\hline
\end{tabular}

\section{ACKNOWLEDGMENT}

The authors are thankful to the School of Environment and Sustainable Development, Central University of Gujarat, Gandhinagar, Gujarat for providing the facilities.

\section{REFERENCES}

[1] R.K. Gautam, M.C. Chattopadhyaya, S.K. Sharma, "Biosorption of heavy metals: recent trends and challenges". In: S.K. Sharma, R. Sanghi (Ed.s.), Wastewater Reuse and Management, Springer, London, pp.305-322. 2013.
[2] J.C. Lee, Y.O. Son, P. Pratheeskumar, X.L. Shi, "Oxidative stress and metal carcinogenesiss". Free Radical Biol Med, Vol.53 pp.742-757. 2012.

[3] P.C. Nagjyoti, K.D. Lee, T.V.M. Sreekanth, "Heavy metals, occurrence and toxicity for plants: a review". Environmental Chemistry Letter, Vol.8, pp.199-216, 2010.

[4] A.S. Stasinakis, N.S. Thomadis, "Fate and biotransformation of metal and metalloid species in biological wastewater treatment processes". Critical Review of Environmental Science and Technology, Vol.40, pp.307-364, 2010.

[5] Q. Manzoor, R. Nadeem, M. Iqbal, R. Saeed, T.M. Ansari, "Organic acids pre-treatment effect on Rosabourbonia phytobiomass for removal of $\mathrm{Pb}$ (II) and Cu(II) from aqueous media". Bioresource Technology, Vol. 132 pp.446-452, 2013.

[6] M. Elkady, H. Shokry, H. Hamad, "Effect of superparamagnetic nanoparticles on the physicochemical properties of nanohydroxyapatite for groundwater treatment: adsorption mechanism of Fe (II) and Mn (II)". RSC Adv Vol. 6, pp.82244-82259, 2016.

[7] N. Rostamnezhad, D. Kahforoushan, E. Sahraei, S. Ghanbarian, M. Shabani, "A method for the removal of $\mathrm{Cu}(\mathrm{II})$ from aqueous solutions by sulfide precipitation employing heavy oil fly ash". Desalination Water Treat. Vol. 57, issue, 37, pp.1-10, 2015.

[8] A. Nędzarek, A. Drost, F.B. Harasimiuk, A. Tórz, "The influence of $p H$ and BSA on the retention of selected heavy metals in the Nanofiltration process using ceramic membrane". Desalination Vol.369, pp.62-67, 2015.

[9] E. Bazrafshan, E. Mohammadi, A. Ansari-Moghaddam, A.M. Mahvi, "Heavy metals removal from aqueous environments by electrocoagulation process-a systematic: review". Journal of Environmental Health Science and Engineering Vol.13, pp.74-89, 2015.

[10] H.A. Hamad, W.A. Sadik, Abd El-latif M.M, A.B. Kashyout, M.Y. Feteha, "Photocatalytic parameters and kinetic study for degradation of dichlorophenol-indophenol (DCPIP) dye using highly active mesoporous $\mathrm{TiO} 2$ nanoparticles". Journal of Environmental Science, Vol.43, pp.26-39, 2016.

[11] Abu Qdais H, H. Moussa, "Removal of heavy metals from wastewater by membrane processes: a comparative study". Desalination Vol.164, issue. 2, pp.105-110, 2004.

[12] B. Ebbers, L.M. Ottosen, P.E. Jensen, "Comparison of two different electrodialytic cells for separation of phosphorus and heavy metals from sewage sludge ash". Chemosphere Vol.125, pp.122-129, 2015.

[13] M. Iqbal, A. Saeed, N. Akhtar, "Petiolar felt sheeth of palm: a new bio sorbent for the removal of heavy metals from contaminated water". Bioresource Technology Vol.81, pp.151-153.

[14] Al-Ashesh S, F. Banat, Al Omar R, Z. Duvnjak, "Predictions of binary sorption isotherms for the sorption of heavy metals by pine bark using single isotherm data". Chemosphere, Vol.41, issue.5, pp.659-665, 2000.

[15] M. Otero, F. Rozada, L.F. Calvo, A.I. Garcia, A. Moran, "Kinetic and equilibrium modelling of the methylene blue removal from solution by adsorbent materials produced from sewage sludges". Biochemical Engineering J, Vol.15, issue.1, pp.59-68, 2003.

[16] M. Shih, "Kinetics of the batch adsorption of methylene blue from aqueous solutions onto rice husk: effect of acid-modified process and dye concentration". Desalination Water Treat Vol.37, issue.13, pp.200-214, 2012.

[17] R.M. Ali, H.A. Hamad, M.M. Hussein, G.F. Malash, "Potential of using green adsorbent of heavy metal removal from aqueous solutions: adsorption kinetics, isotherm, thermodynamic, mechanism and economic analysis". Ecological Engineering, Vol. 91, pp.317-332, 2016.

[18] United Nations Environmental Protection/Global Program of Action (UNEP/GPA) Why the marine environment needs 
protection from heavy Metals, UNEP / GPA Coordination Office. 2004.

[19] H. Ali, E. Khan and M.A. Sajad, "Phytoremediation of heavy metals - concepts and applications". Chemosphere, Vol. 91, pp. 869-81, 2013.

[20] R. Dixit, D. Wasiulah, Malaviya, K. Pandiyan, U.B. Singh, A. Sahu, R. Shukla, B. P. Singh, J. P. Rai, P. K. Sharma, H. Lade and D. Paul, "Bioremediation of heavy metals from soil and aquatic environment: An overview of principles and criteria of fundamental processes". Sustainability, Vol. 7, pp. 2189-212, 2015.

[21] I. Raskin, R. D. Smith and D. E. Salt, "Phytoremediation of metals: using plants to remove pollutants from the environment". Current Opinion in Biotechnology, Vol. 8, pp. 221-228, 1997.

[22] M. M. Lasat, "Phytoextraction of metals from contaminated soil: a review of plant/soil/metal interaction and assessment of pertinent agronomic issues" J. Hazardous Substance Res. Vol.2, pp. 1-25, 2000.

[23] A. Gaur and A. Adholeya, "Prospects of arbusclar mycorrhizal fungi in phytoremediation of heavy metal contaminated soils." Current Science, Vol. 86, issue.4, pp. 528-34, 2004.

[24] A. Buasri, N. Chaiyut, K. Tapang, S. Jaroensin, S. Panphron, "Equilibrium and kinetic studies of biosorption of Zn(II) ions from wastewater using modified corn cob. APCBEE Procedia Vol.3, pp. 60-64, 2012.

[25] L. Zheng, Z. Dang, X.Yi, H. Zhang, "Equilibrium and kinetic studies of adsorption of Cd(II) from aqueous solution using modified corn stalk. Journal of Hazardous Materials, Vol. 176, pp.650-656, 2010a.

[26] L. Zheng, Z. Dang, X. Yi, H. Zhang, "Removal of cadmium (II) from aqueous solution by corn stalk graft copolymers". Bioresource Technology, Vol. 101, pp. 5820-5826, 2010b.

[27] K.K. Wong, C.K. Lee, K.S. Low, M.J. Haron, "Removal of $\mathrm{Cu}$ and $\mathrm{Pb}$ by tartaric acid modified rice husk from aqueous solutions". Chemosphere, Vol. 50, pp.23-28, 2003.

[28] E. Khoramzadeh, B. Nasernejadb, R. Halladj, "Mercury biosorption from aqueous solutions by Sugarcane Bagasse". J Taiwan Inst Chem Eng, Vol. 44, pp.266-269, 2013.

[29] B. Pejic, M. Vukcevic, M. Kostic, P. Skundric, "Biosorption of heavy metal ions from aqueous solutions by short hemp fibers: Effect of chemical composition". Journal of Hazardous Materials, Vol. 164, pp.146-153, 2009.

[30] A. Ismail, D.B. Adie, A. Oke, J.A. Otun, N.O. Olarinoye, S. Luckman, C.A. Okufu, "Adsorption kinetics of cadmium ions onto powdered corn cobs". Can J Chem Eng Vol. 87, pp.896-909, 2009.

[31] T. Ding, S. Hii, L. Ong, "Comparison of pre-treatment strategies for conversion of coconut husk fiber to fermentable sugars". Bioresource, Vol. 7, issue.2, pp.1540-1547, 2012.

[32] M. Gorgievski, D. Božić, V. Stanković, N. Štrbac, S. Šerbula, "Kinetics equilibrium and mechanism of $\mathrm{Cu}^{2+}, \mathrm{Ni}^{2+}$ and $\mathrm{Zn}^{2+}$ ions biosorption using wheat straw". Ecological Engineering, Vol. 58, pp.113-121, 2013.

[33] R. Elangovan, L. Philip, K. Chandraraj, "Biosorption of hexavalent chromium by palm flower (Borassusaethiopum)". Chem Eng J, Vol.141, pp.99-111, 2008.

[34] S. Malathi, N. Krishnaveni, R. Sudha, "Adsorptive removal of lead (II) from an aqueous solution by chemically modified cotton seed cake". Res Chem Intermediat 1-18, 2015.

[35] F. Bouhamed, Z. Elouear, J. Bouzid, "Adsorption removal of copper (II) from aqueous solutions on activated carbon prepared from Tunisian date stones: Equilibrium, kinetics and thermodynamics". Journal of Taiwan Institute of Chemical Engineers, Vol. 43, issue.5, pp.741-749, 2012.
[36] M. Jalali, F. Aboulghazi, "Sunflower stalk, an agricultural waste, as an adsorbent for the removal of lead and cadmium from aqueous solutions". Journal of Material Cycles Waste Management, Vol. 15, pp.548-555, 2013.

[37] G. García-Rosales, A. Colín-Cruz, "Biosorption of lead by maize (Zea mays) stalk sponge". Journal of Environmental Management, Vol. 91, pp.2079-2086, 2010.

[38] N. Ahalya, R.D. Kanamadi, T.V. Ramachandra, "Biosorption of chromium (VI) from aqueous solutions by the husk of Bengal gram (Cicer arientinum)". Electron J Biotechn, Vol.8, pp.258-264, 2005.

[39] W.E. Oliveira, A.S. Franca, L.S. Oliveira, S.D. Rocha, "Untreated coffee husks as bio sorbents for the removal of heavy metals from aqueous solutions". Journal of Hazardous Materials, Vol.152, pp.1073-1081, 2008.

[40] M. Imamoglu, H. Yıldız, H. Altundag, Y. Turhan, "Efficient Removal of $\mathrm{Cd}$ (II) from Aqueous Solution by Dehydrated Hazelnut Husk Carbon". Journal of Dispersion Science and Technology, Vol. 36, issue. 2, pp.284-290, 2014.

[41] S. Sobhanardakani, H. Parvizimosaed, E. Olyaie, "Heavy metals removal from wastewaters using organic solid waste-rice husk". Environmental Science and Pollution Research, Vol. 20, pp.5265$5271,2013$.

[42] L.H. Velazquez-Jimenez, A. Pavlick, J.R. Rangel-Mendez, "Chemical characterization of raw and treated agave bagasse and its potential as adsorbent of metal cations from water". Ind Crop Prod, Vol.43, pp.200-206, 2013.

[43] D. Mohan, K.P. Singh, "Single- and multi-component adsorption of cadmium and zinc using activated carbon derived from bagasse-an agricultural waste". Water Res, Vol.36, pp.23042318, 2002.

[44] K.K. Krishnani, X. Meng, L. Dupont, "Metal ions binding onto lignocellulosic bio sorbent. Journal of Environmental Science and Health, Part A:" Toxic/ Hazardous Substances and Environmental Engineering, Vol.44, pp.688-699, 2009.

[45] M.Á. Martín-Lara, I.L.R Rico, I.C.A. Vicente, G.B. García, Hoces de MC, "Modification of the sorptive characteristics of sugarcane bagasse for removing lead from aqueous solutions". Desalination, Vol. 256, pp.58-63, 2010.

[46] dos Santos W.N.L., D.D. Cavalcante, da Silva E.G.P, CF d V, FS $\mathrm{D}$, "Biosorption of $\mathrm{Pb}$ (II) and Cd(II) ions by Agave sisalana (sisal fiber)". Microchemical Journal, Vol.97, pp.269-273, 2011.

[47] K. Johari, N. Saman, S.T. Song, J.Y.Y. Heng, H. Mat, "Study of Hg(II) Removal From Aqueous Solution Using Lignocellulosic Coconut Fiber Bio sorbents: Equilibrium and Kinetic Evaluation". Chem Eng Commun, Vol.201, pp.1198-1220, 2014.

[48] H.N. Bhatti, I.I. Bajwa, M.A. Hanif, I.H. Bukhari, "Removal of lead and cobalt using lignocellulosic fiber derived from Citrus reticulata waste biomass". Korean J Chem Eng, Vol. 27, issue.1, pp.218-227, 2010.

[49] V.K. Gupta, D. Pathania, S. Agarwal, S. Sharma, "Removal of $\mathrm{Cr}(\mathrm{VI})$ onto Ficus carica bio sorbent from water. Environ Sci Pollut R Vol.20, pp.2632-2264, 2013.

[50] A.E. Ofomaja, "Equilibrium studies of copper ion adsorption onto palm kernel fibre". Journal of Environmental Management, Vol. 91, pp.1491-1499, 2010.

[51] C.P.J. Isaac, A. Siva Kumar, "Removal of lead and cadmium ions from water using Annona squamosa shell: kinetic and equilibrium studies". Desalina Water Treat Vol.51, pp.7700-7709, 2013.

[52] P.S. Kumar, S. Ramalingam, R.V. Abhinaya, K.V. Thiruvengadaravi, P. Baskaralingam, S. Sivanesa, "Lead (II) Adsorption onto Sulphuric Acid Treated Cashew Nut Shell. Sep Sci Technol, Vol.46, pp.2436-2449, 2011. 
[53] O.S. Amuda, O.I. Ojo, T.L. Edewor, "Biosorption of Lead from Industrial Wastewater Using Chrysophyllum albidum Seed Shell". Bioremediation Journal Vol.11, issue.4, pp.183-194, 2007.

[54] J.C.P. Vaghetti, E.C. Lima, B. Royer, N.F. Cardoso, B. Martins, T. Calvete, "Pecan Nutshell as Biosorbent to Remove Toxic Metals from Aqueous Solution". Sep Sci Technol Vol.44, pp.615-644, 2009.

[55] M. Zabihi, A. Ahmadpour, A. Haghighi Asl A, "Removal of mercury from water by carbonaceous sorbents derived from walnut shell". J Hazard Mater Vol.167, pp.230-236, 2009.

[56] E. Pehlivan, T. Altun, S. Cetin, M.I. Bhanger, "Lead sorption by waste biomass of hazelnut and almond shell". Journal of Hazardous Materials, Vol.167, pp.1203-1208, 2009a.

[57] E. Pehlivan, T. Altun, S. Parlayici, "Utilization of barley straws as biosorbents for $\mathrm{Cu} 2+$ and Pb2+ ions". Journal of Hazardous Materials, Vol.164, pp.982-986, 2009b.

[58] J. Wang, T. Chen, S. Li, Z. Yue, J. Jin, G. He, H. Zhang, "Biosorption of Copper (II) from Aqueous Solutions with Rape Straw". Geomicrobiol J, Vol.29, pp.250-254, 2012.

[59] V.B.H. Dang, H.D. Doan, T. Dang-Vu, A. Lohi, "Equilibrium and kinetics of biosorption of cadmium (II) and copper (II) ions by wheat straw". Bioresource Technology, Vol. 100, pp.211-219, 2009.

[60] M. Abbas, S. Kaddour, M. Trari, "Kinetic and equilibrium studies of cobalt adsorption on apricot stone activated carbon". J Ind Eng Chem, Vol.20, pp.745-751, 2014.

[61] J. Anand kumar, B. Mandal, "Removal of Cr (VI) from aqueous solution using bael fruit (Aegle marmeloscorrea) shell as an adsorbent". Journal of Hazardous Materials, Vol.168, pp.633-640, 2009.

[62] K.A. Krishnan, T.S. Anirudhan, "Kinetic and equilibrium modelling of cobalt (II) adsorption onto bagasse pith based sulphurised activated carbon". Chem Eng J, Vol. 137, issue.2, pp.257-264, 2008.

[63] H. Parab, S. Joshi, N. Shenoy, A, Lali, U.S. Sarma, M. Sudersanan, "Determination of kinetic and equilibrium of Co (II), $C(I I I)$, and Ni(II) onto coir pith". Process Biochem, Vol. 41, pp.609-615, 2006.

[64] P.S. Vankar, R. Sarswat, D.S. Malik, "Biosorption of lead and cadmium ions from aqueous solutions onto natural dye waste of Hibiscus rosa sinensis". Environ Prog Sustain Energy, Vol. 29, pp. 421-427, 2010.

[65] S. Nigam, K. Gopal, P.S. Vankar, "Biosorption of arsenic in drinking water by submerged plant: Hydrilla verticilata". Environmental Science Pollut R, Vol.20, pp. 4000-4008, 2013.

[66] C.T. Kamala, K.H. Chu, N.S. Chary, P.K Pandey, S.L. Ramesh, A.R.K. Sastry, Sekhar, "Removal of arsenic (III)from aqueous solutions using fresh and immobilized plant biomass". Water Resource, Vol.39, pp.2815-2826, 2005.

[67] V. Venugopal, K. Mohanty, "Bio sorptive uptake of Cr (VI) from aqueous solutions by Parthenium hysterophorus weed: Equilibrium, kinetics and thermodynamic studies. Chem Eng J, Vol.174, pp.151-115, 2011.

[68] H. Lata, V.K Garg, R.K. Gupta, "Sequestration of nickel from aqueous solution onto activated carbon prepared from Parthenium hysterophorus L." Journal of Hazardous Materials. Vol.157, pp.503-509, 2008.

[69] M. Momčilović, M. Purenović, A. Bojić, A. Zarubica, M. Ranđelović, "Removal of lead(II) ions from aqueous solutions by adsorption onto pine cone activated carbon". Desalination, Vol.276, pp.53-59, 2011.

[70] S.S. Baral, S.N. Das, G.R. Chaudhury, Y.V. Swamy, P. Rath, "Adsorption of $\mathrm{Cr}(\mathrm{VI})$ using thermally activated weed Salvinia cucullata". Chem Eng J, Vol.139, pp.245-255, 2008.
[71] B. Shrestha, P.L. Homagai, M.R. Pokhrel, K.N. Ghimire, "Exhausted tea leaves- a low-cost adsorbent for the removal of lead (II) and zinc (II) ions for their aqueous solution". J Nepal Chem Soc Vol.30, pp.123-129, 2012.

\section{AUTHORS PROFILE}

Pankaj Kumar is currently working as Ph.D. Research Scholar in School of Environment and Sustainable Development, Central University of Gujarat, Gandhinagar. He has been awarded the UGC Rajiv Gandhi National Fellowship (RGNF) and presently he is working as a UGC RGNF Senior Research Fellow. His research area deals with Rhizosphere Bioremediation of heavy metals from soil using plants. He has completed M.Sc. in Ecology and Environmental Sciences from Pondicherry Central University, Pondicherry in 2013. He has also received M.Phil. From the Central University of Gujarat, Gandhinagar in 2016.

Indra Jeet Chaudhary is currently working as Ph.D. Research Scholar in School of Environment and Sustainable Development, Central University of Gujarat, Gandhinagar. Currently, he is working on the project 'Impact Assessment of Ozone Pollution on selected Crop plant of Gujarat'. He has published various research articles in the field of plant stress physiology, Urban Forestry, Organic manures, and Organic matrix-based biofertilizer, Agricultural sustainability and Pollution risk assessment.

Snigdha Singh is currently working as $\mathrm{Ph} . \mathrm{D}$. Research Scholar in School of Environment and Sustainable Development, Central University of Gujarat, Gandhinagar. She has been awarded the UGC Rajiv Gandhi National Fellowship (RGNF) and presently she is working as UGC RGNF Senior Research Fellow. 